\title{
СРЕДСТВА РЕПРЕЗЕНТАЦИИ КОНЦЕПТОВ ОСЕНЬ И ВЕСНА В ЛИНГВОКУЛЬТУРЕ РУССКОГО И УЗБЕКСКОГО ЯЗЫКОВ Отабек Тимурович НОСИРОВ
}

Старший преподаватель

Завкафедрой русского языка и литературы

Бухарский государственный университет

Бухара, Узбекистан

\author{
РУС ВА ЎЗБЕК ЛИНГВОМАДАНИЯТИДА КУЗ ВА БАХОР \\ КОНЦЕПТЛАРИНИ АКС ЭТТИРИШ ВОСИТАЛАРИ \\ Отабек Тимурович НОСИРОВ \\ Катта ўқитувчи \\ Рус тили ва адабиёти кафедраси мудири \\ Бухоро давлат университети \\ Бухоро, Ўзбекистон
}

\section{MEANS OF REPRESENTATION OF THE CONCEPTS AUTUMN AND SPRING IN THE LINGUOCULTURE OF THE RUSSIAN AND UZBEK LANGUAGES Otabek NOSIROV}

Senior Lecturer

Head of the Department of Russian Language and Literature

Bukhara State University

Bukhara, Uzbekistan xxx.otash77@mail.ru

UDC (УўК, УдК): 811.161.1: 811.512.133 For citation (иқтибос келтириш учун,
для цитирования):

Носиров О.Т. Средства репрезентации концептов осень и весна в лингвокультуре русского и узбекского языков //

Ўзбекистонда хорижий тиллар. - 2021. № 1 (36). - C. 65-78.

https://doi.org/10.36078/1618559121

Received: November 12, 2020

Accepted: January 17, 2021

Published: February 20, 2021

Copyright (c) 2021 by author(s) and Scientific Research Publishing Inc.

This work is licensed under the Creative Commons Attribution International License (CC BY 4.0).

http://creativecommons.org/licenses/by/4.0/

\section{Open Access}

Аннотация. В статье рассмотрены аспекты выражения концептов Осень и Весна, входящих в концептосферу Времена года в русской и узбекской лингвокультурах. Также произведён подробный анализ понятий осень и весна в толковых словарях узбекского языка, изданных в разный период. В современных толковых словарях узбекского языка значения времён года имеют как сходства, так и различия: это наблюдается не только в отношении зимы и лета, но и в оформлении дефиниций весны и осени. Содержание концептов Осень, Весна связано с культурноценностными доминантами русской и узбекской культур, а их этнокультурные отличия проявляются в каждом из слоев концепта на этимологическом, семантическом, образном, понятийном, ассоциативном, символическом уровнях. В статье это рассмотрено на основе узбекских пословиц и поговорок, которые и в XXI веке сохранили в себе элементы ритуальнообрядовых традиций, свидетельствующих о том, что формирование и наполнение концепта непосредственно связано с формированием и развитием мифопоэтики народа, бережно сохраняемой и передаваемой из поколения в поколение.

Ключевые слова: сопоставительная лингвистика; концепт; концептосфера; когнитивные признаки; пословицы; загадки; базовое ядро; периферия; ассоциации; ассоциативный ряд.

Аннотация. Мақолада «йил фасллари» концептосферасига киритилган «куз» ва «бахор» тушунчаларининг рус ва ўзбек 
лингвистик маданиятларида ифодаланиш жихатлари кўриб чиқилди. Турли йилларда нашр этилган ўзбек тилининг изохли луғатларида хам «куз» ва «бахор» тушунчалари батафсил тахлил қилинди. Ўзбек тилининг хозирги изохли луғатларида йил фаслларининг маъноларида хам ўхшашлик, хам баъзи фарқлар мавжуд: бу нафақат ёзнинг қишга нисбатан, балки бахор ва кузнинг таърифлари фарқларида хам кузатилади. «Куз, бахор» тушунчаларининг мазмуни рус ва ўзбек маданиятларининг маданий ва қадрият доминантлари билан боғлиқ бўлиб, уларнинг этно-маданий фарқлари тушунчанинг хар бир қатламида этимологик, семантик, образли, концептуал, ассоциатив, рамзий даражаларда намоён бўлади. Мақолада бу тушунчанинг шаклланиши ва мазмуни бевосита халқ мифопоэтикасининг ривожланиши билан боғлиқ эканлиги кўрсатилиб, XXI асрда маросим ва маросим анъаналари элементларини пухта сақлаб қолган хамда авлоддан-авлодга узатилган уззбек мақол ва маталлари асосида кўриб чиқилди.

Калит сўзлари: таққослаш лингвистикаси, концепт, концептосфера, когнитив белгилар, мақоллар, топишмоқлар, таянч асоси, атрофидаги сўзлар, ассоциациялар, ассоциатив қатор.

Abstract. The article considers the aspects of expressing the concepts Autumn and Spring within the frame of the conceptual sphere Seasons in the Russian and Uzbek lingua-cultures. A detailed analysis of the concepts of Autumn and Spring in the explanatory dictionaries of the Uzbek language, published in different periods, has been made. In modern explanatory dictionaries of the Uzbek language, the meanings of the seasons have both similarities and differences: This is observed not only in relation to the winter of summer but also in designing the definitions of spring and autumn. The content of the concepts Autumn, Spring dominants of Russian and Uzbek cultures and their ethnocultural differences are manifested in each of the layers of the concept at the etymological, semantic, figurative, conceptual, associative and symbolic levels. The analysis has been made on the material of the Uzbek proverbs and sayings, which in the 21 century have preserved elements of rituals and traditions, indicating that the formation and content of the concept are directly related to the formation and development of the myth poetics of the people, carefully preserved and transmitted from generation to generation.

Keywords: comparative linguistics; concept; conceptosphere; cognitive features; proverbs; riddles; basic core; periphery; associations; associative series.

Введение. Современная лингвистика, и когнитивная лингвистика в частности, наряду с терминами «концепт» и «концептосфера», активно оперируют терминологическим сочетанием «языковая картина мира» и «репрезентация». Эти широко распространенные и активно развивающиеся в настоящее время термины объектом своего изучения определяют те невидимые глазу процессы, в ходе которых тонкие ментальные элементы национальнокультурного наследия закрепляются в сознании/подсознании как индивида, так и коллектива, народа и нации в целом, и как данные ментальные элементы в дальнейшем реализуются вербально, в процессе речевых актов, являясь результатом взаимодействия мышления, окружающей действительности, эмоциональных реакций и языка (речи). 
Основная часть. В современных узбекских словарях значения времен года имеют как сходства, так и различия: это наблюдается не только в отношении зимы и лета, но и в оформлении дефиниций весны и осени. Так, например, в «Ўзбек тилининг изохли луғати» (далее ЎТИЛ) под редакцией Э.М. Маъруфова определение весны дано следующим образом: 1. «Тўрт фаслнинг биринчиси, қишдан кейинги, ёздан олдинги фасл; кўклам» 2. кўчма Хам нарсанинг, масалан, умрнинг, хаётнинг гулгун, яшнаган чоғлари ва шундай чоғлар рамзи $(11,91)$. Данное определение акцентирует внимание на:

1) Последовательности времен года (весна следует за зимой и предшествует лету).

2) На традиционно-историческом восприятии весны как первого среди сезонов (тугрт фаслнинг биринчиси). В отличие от принятого современного календарного порядка, словарь называет первым сезоном не зиму, (переломным моментом которой служит календарный новый год 31-го декабря), а весну, т.е. следует логике исторической традиции празднования весеннего праздника встречи нового года Навруза. Такой порядок следования времен года отразился в узбекском фольклоре в виде пословицы Йилнинг яхии келиши бахэордан маълум - Наступающий год известен с весны.

3) На дополнительном, метафорическом значении весны в параллели со всеми лучшими аспектами человеческой жизни: молодости и т.д.

Изданный в 2006-2008 годах «Ўзбек тилининг изохли луғати» под редакцией Э. М. Мадвалиева $(12,195-196)$, в отличие от ЎТИЛ 1981-го года, дает более широкую дефиницию весны, указывая не только на названия календарных месяцев весны (март, апрель и май), но и большее, по сравнению с ЎТИЛ 1981, количество прямых и переносных значений. Кроме того, указано значение слова весна (Бахуор) как узбекского женского имени собственного: 1. «Йилдаги тўрт фаслнинг бири, қишдан кейинги, ёздан олдинги фасл; кўклам (йилниг март, апрель, май ойларига тўғри келади)». 2. Кўкламга мансуб, хос; яшил, ям-яшил. 3. куичма Умрнинг маълум қисми, муддати, ёши. 4. куцчма Кувонч, шодлик, бахт. 5. кўчма Севги, мухаббат; умид. 6. кўчма Севгили маъшуқа, гўзал ёр. 7. Бахор (хотин-қизлар исми).

Вынос в скобки названий календарных месяцев весны целесообразен, поскольку авторы стремятся наиболее точно отразить календарные характеристики сезона, в отличие от ЎТИЛ-1981, который подчеркивает, что весенние климатические особенности Узбекистана не совпадают с календарными весенними месяцами григорианского календаря в других климатических зонах и других странах Евразии. Переносные значения, данные в словаре под редакцией Э. М. Мадвалиева (12, 195-196), дополняют переносные значения, данные в ЎТИЛ-1981, усиливая акцентуацию на значении весны как лучшего, наиболее яркого и радостного среди периодов человеческой жизни. Отметим важность определения весны как женского имени, поскольку больше не одно из времен года, кроме весны, в узбекском языке не перешло в разряд имен собственных. Это, на наш взгляд, подчеркивает положительную характеристику, и значимость данного времени года в узбекской языковой картине мира.

В обоих словарях при определении весны дано слово «кўклам» - синоним «бахор». Словарь под редакцией Э. М. Мадвалиева дает следующее определение данному слову: «Йилнинг қиш билан ёз оралиғидаги фасли; бахор» $(12,451)$. Хотя в смысловом отношении 
формулировка определения совпадает (период времени года между зимой и летом), однако, в отличие от определения к бахуор, в этом определении отсутствуют названия календарных месяцев и переносные значения. Отметим, что синоним наблюдается в словаре только для слова бахуор, для осени, зимы и лета синонимы отсутствуют. Кўклам встречается в узбекском языке менее активно, в качестве более возвышенного, поэтического слова. Как, например, в заголовке репортажа Национального агентства новостей Узбекистана от 20.02.2013 г.: «Андижонда кугклам нафаси». Слово использовано только в заголовке, в дальнейшем тексте использовано слово бахэор: Баххо куёшининг илиқ тафти сезилиб қолган шу кунларда барча жойларда бўлгани каби Андижон шахрида хам ободонлаштириш, кўкаламзорлаштириш ишлари тобора қизғин паллага кирмокда (1).

В отличие от весны (а также лета и зимы), дефиниция осени в ЎТИЛ-2006 полностью совпадает с ЎТИЛ-1981. Сравним:

1. Ёз билан қиш ўртасидаги фасл. 2. кўчма Даврнинг, ма киши хаётининг умрнинг охирги дамлари $(11,402)$.

1. Ёз билан қиш ўртасидаги фасл. 2. кўчма Даврнинг, ма киши хаётининг умрнинг охирги дамлари $(12,420)$.

Акцентирование на перечислении названий осенних месяцев (т.е. сентябрь, октябрь, ноябрь), в ЎТИЛ-2007, в отличие от словарной статьи «весна» или «зима», отсутствует. Отметим также, тот факт, что уточнение в виде перечисления названий календарных месяцев в словаре под редакцией Э. М. Мадвалиева присутствует только в дефинициях зимы и весны, но отсутствует для лета и осени, хотя целесообразнее было бы дать такое уточнение для каждого из времен года.

Таким образом, определение осени в ЎТИЛ под редакцией Э.М. Маъруфова и в ЎТИЛ под редакцией Э. М. Мадвалиева совпадают, тогда как к определению весны, составители словарей подошли с различных точек зрения. Это важно, поскольку отражает концептуальные характеристики весны в Центрально-Азиатском регионе в целом и в Узбекистане в частности. Мы уже не раз отмечали тот важный для понимания концептов концептосферы «Времена года» факт, что традиция празднования зимой не была свойственна восточным культурам до первой четверти XX-го столетия, и, несмотря на эту, очевидно заимствованную и благополучно прижившуюся традицию, в Узбекистане и ряде других стран Центрально-Азиатского региона параллельно сохранилась традиция празднования нового года 21-го марта, в день весеннего равноденствия и наступления нового солнечного цикла. Данный факт и служит ответом, почему не зима, осень или лето, а именно весна пополнила ряд женских имен в узбекском языке.

Празднование весеннего нового года - Навруза, связанного с многовековым земледельческим опытом и наблюдениями за природой, сохранилось и после принятия ислама. Например, в средние века в Бухаре этот праздник назывался «Наврўзи кишаворзон» - «Навруз земледельцев», поскольку земледельцы (дехкане) именно в этот день выводили на поля упряжки волов и высеивали в землю первые семена (6). Эта земледельческая традиция, подчеркивающая важность весенних полевых работ в предстоящей заготовке пропитания для выживания зимой, отразилась в таких пословицах: 
Бахуорнинг бир куни бир йилни туйдиради - Один весенний день год кормит;

Бахуорнинг бир куни йилга таътир - Один весенний день основа года;

Бахорнинг бир куни құишни боқ̧ар - Один весенний день приглядывает за зимой.

Несомненно, речь идет не о празднике Навруз как таковом, но о благоприятных погодных условиях весны, в частности периоде, когда любой день «горит», требуя усилий в сельскохозяйственных работах.

Следует отметить, что в узбекские пословицы о весне зачастую вплетена и идея о весеннем труде, поэтому пословицы о весне встречаются не только среди пословиц о временах года, но и в категории, связанной с трудовой деятельностью людей и еe результатами, проявляющимися в осенний период, например:

Бахуорги хуаракат - кузги баракат - Весенние работы осеннее благо, т.е. результаты хорошей работы весной очевидны осенью вместе с богатым урожаем. Ср. русскую пословицу $\mathrm{He}$ потопаешь - не полопаешь.

Бахуорги бегамлик - кузги пушимнлик - Безразличие весной сожаление осенью. Именно весна — наиболее благоприятный период для проведения земледельческих работ в регионе, т.к. земля смягчена и увлажнена дождями, а реки, откуда поступает поливная вода для посевов, полноводны за счет таяния снега в горах и дождей, в отличие от лета, когда земля иссушена, а уровень воды в реках спадает и требуются усилия для полива. Следовательно, весна - это период, наиболее благоприятный и который нельзя игнорировать, если желаешь получить хороший урожай осенью (иначе будешь сожалеть).

Кўклам - мехнат билан кууркам - Весна - красота пополам с трудом. Любование красотами весенней природы не освобождает от необходимости трудиться ради пропитания (5).

Информация о Наврузе запечатлена в произведениях Махмуда Кашгари, Абу Райхана Беруни, «Наврузнаме» Омара Хайяма, у Алишера Навои и Захириддина Бабура и других выдающихся литературных деятелей, поскольку празднования являлись массовым явлением и отмечались повсеместно: проращивалась пшеница, и из ее ростков варили традиционное блюдо - сумалак, организовывались такие народные игры, как скачки, улак, кураш, проводились гуляния с песнями о весне и т.п. На сегодняшний день Навруз является одним из 6 объектов Узбекистана, включенных в Репрезентативный список нематериального культурного наследия человечества ЮНЕСКО (6).

Итак, в базовом ядре концепта Весна в узбекском языке находится национально-специфическое, непереводимое понятие Навруз, близкое и понятное носителям языков сопредельных стран Каракалпакстана, Таджикистана, Туркменистана, Казахстана и т.д., но требующее пояснения для носителей русского языка не рожденных и/или не проживающих на территории Центральной Азии, а также для представителей других культур, исторически не имевших тесного соприкосновения с культурой и менталитетом центральноазиатских народов $(4,65-66)$. Также в базовом слое концепта Весна наблюдаем и непереводимое понятие сумаляк, неразрывно связанное с понятием весна, и праздник Навруз. Важность понятия сумаляк для понимания концепта Весна в узбекском языке сложно оценить; в течение 
тысячелетий оно подверглось мифологизации, ритуализации, обросло легендами и сакральным смыслом. В работе, посвященной мифологическим представлениям в узбекских загадках, М. Ю. Джураева приводит в качестве примера загадку, записанную и переведенную на русский язык в 1958 г. фольклористом 3. Хусаиновой:

\section{Товда талаймонни куцрдим, \\ Сувда сулаймонни кйрдим, \\ Юмалаб ётган тошни куррдим, \\ Тузсиз пишган ошни кўрдим.}

(На горе я увидел кусачего, // В воде увидел плавающего,// Увидел я лежаший камень, Увидел блюдо, приготовленное без соли) (3, 47-49).

Отгадка данной загадки таится в четырех объектах: волк, рыба, черепаха и сумалак, где в последней строчке «Тузсиз пишган ошни куррдим» (Увидел блюдо, приготовленное без соли) дается характеристика сумаляка, с приготовлением которого связаны различные ритуалы, обычаи и поверья. «...бытует поверье, что «sumalak - это священная еда Биби Фотимы» (культ святой Биби Фотимы, олицетворяющей в себе антропоморфный облик исламизированного образа богини-матери и символ плодородия, широко распространен в Средней Азии). <..> По традиции, перед началом приготовления сумалака очаг окуривают дымом «isiriq» (гармала) и на масле жарят специальное ритуальное мучное блюдо «богурсак» (для его изготовления соль не употребляется). Этот обычай называется «выделять запах». Таким образом, угощаются духипокровители семейного очага. < .. > На рассвете, когда глаза уставших женщин слипаются под действием желания уснуть, Биби Фотима собственноручно солит сумалак. Говорят, поэтому при приготовлении сумалака не принято его солить <...> $(3,49)$. Мифологизации подвергся и камень, упомянутый в загадке, поскольку имеется в виду специально подготовленный и мытый камень (камни), который кладут на самый низ котла, чтобы густое варево сумалака при длительном процессе его приготовления не пригорело.

В узбекском языке существуют пословицы, связанные с Наврузом как точкой отсчета сезонов, например, Наврўздан сўнг қиш бўлмас, Мизондан сўнг ёз бўлма - После Навруза зимы не бывает, после месяца мизана (в некоторых источниках встречается также написание мезон) - название седьмого месяияа Солнечного года в тюркских языках (с 22 сентября по 21 октября) лета не бывает, т.е. Навруз символизирует окончательное наступление стабильно теплой погоды, позволяющей приступить к сельскохозяйственным работам. Навруз так же, как и Бахор, пополнило ряды имен собственных (мужских) в узбекском языке, а стихов и песен, посвященных данному празднику, существует огромное количество, как, например, «Наврўз кўшиғи» в стихотворном сборнике «.. Ўзингни совиниб келади, Навруз!» поэта Иқбола Мирзо; включая такой современный и малоизученный подвид поэзии, как стихотворные смс-тексты для поздравления по телефону, доступные в сети Интернет, например:

Севинчдан куизимда ёш,

Ўзгача порлар куёш,

Қутлар сени қ̧ари, ёш,

Хуш келибсан Наврўзой! (9) 
Сохранившиеся и в XXI веке элементы ритуально-обрядовых традиций свидетельствуют о том, что формирование и наполнение концепта непосредственно связано с формированием и развитием мифопоэтики народа, бережно сохраняемой и передаваемой из поколения в поколения. Анализ ассоциативного ряда, подготовленный на основании ответов респондентов (облако ассоциаций) позволило нам не только определить и разграничить коллективные и индивидуальные ассоциации, связанные с весной, формирующие базовый и периферийные когнитивные слои наполнения концепта, но и позволило выявить национально-культурную специфику концепта Весна, сформировавшуюся под влиянием этой мифопоэтики в обыденном сознании индивида:

Рис. 4. Представление ассоциативного ряда (облако ассоциаций) к концепту Весна в узбекском языке

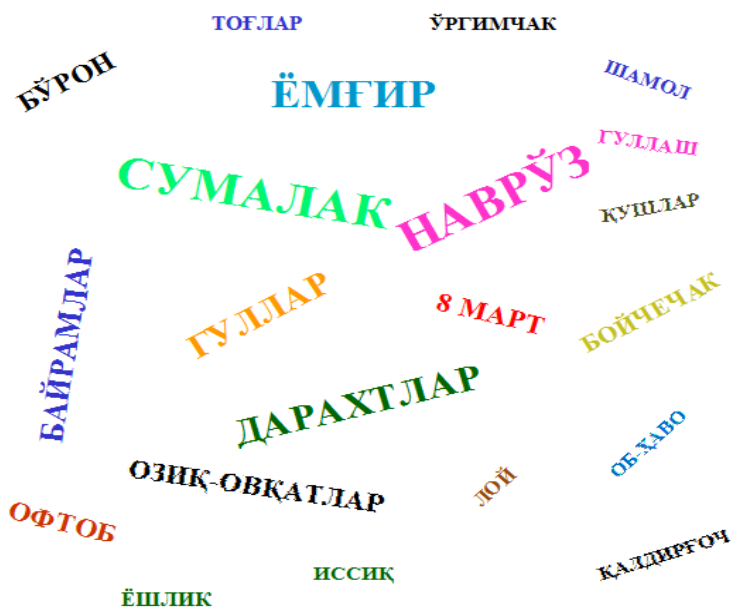

В качестве ассоциации со словом весна респонденты, как монолингвы, так и билингвы, практически единодушно указывали Навруз и сумаляк. Следующим по частотности ответов явилась ассоциация с ёмzир (дождь), что закономерно, так как весна в Ташкенте и Ташкентской области, а также других областях республики характеризуется частыми, обильными и кратковременными осадками с грозами и молниями, а иногда сильными бурями в преддверие жаркого и засушливого лета. Буррон (буря) также присутствует в облаке ассоциаций, но менее частотно, поскольку такое явление, как, например, ураган 27 апреля 2020 года в Бухаре и Бухарской области (7), повлекший за собой многочисленные разрушения и даже жертвы, наблюдается реже, чем просто сильные дожди, не каждый год и не в каждой области. Как и в ассоциациях к зиме, среди когнитивных признаков весны отмечена единичная ассоциация лой (грязь). Однако данная ассоциация менее частотна в случае весны, так как весенние осадки, как правило, кратковременны, и глинистая почва Ташкента и Ташкентской области довольно быстро впитывает влагу. Таким образом, данная ассоциация индивидуальна и располагается на периферийном слое концепта.

В сознании носителей узбекского языка весна ассоциируется не только с байрамлар (праздники), где на первом месте всегда Навруз, но и с праздником 8-го Марта - сравнительно недавно заимствованным в узбекской культуре, но не менее популярным, так как позволяет выразить почтение как женщинам в целом, так и в частности матерям. 
Уважение и почитание матери в центральноазиатских культурах неоспоримо, и закономерно способствовало популяризации данного праздника и его вхождению в состав когнитивных признаков концепта Весна. Что же касается праздника 9 Мая, то среди ассоциаций в связи с весной он не был упомянут ни разу, однако в перспективе, в течение последующих пяти - десяти лет, этот праздник имеет шансы войти в узбекскую языковую картину мира поколений, родившихся после 2000 года, как когнитивный признак концепта Весна.

Можно отметить взаимосвязь образа весны с праздниками и в авторской скороговорке: Бахор байрамларига бажонидил боргим бор - С удовольствием еду на весенние праздники $(2,5)$.

Закономерно, что весна в узбекской языковой картине мира ассоциируется с красотой природы: мы отмечаем это благодаря таким ассоциациям, связанным с пробуждением растительного мира, как дарахтлар (деревья) и гуллар (цветы), поскольку на период равноденствия (Навруз) приходится этап интенсивного цветения. Это и подснежники, крокусы, тюльпаны и маки в горах, плодовые деревья, травы. Поскольку лето, в отличие от весны, - засушливый период года, когда садовые и полевые культуры требуют усиленного полива, то именно весна с ее дождями являет в Узбекистане наиболее яркие краски окружающей среды. Этот факт кумулируется и в детских загадках:

\author{
Бола келар, бола келар, \\ Илк мехр ола келар, \\ Силаб-сийлаб дарахтларга, \\ Гулдан маржон така келар (Бахуор).
}

Ребенок идет, ребенок идет // Первым прибыл - первым обслужен (эквивалент в русском языке: поздний гость гложет и кость) // Поглаживая деревья, Из цветка получается ожерелье (Весна).

Отметим, что ассоциация с бойчечак (подснежник) стала единичной, несмотря на сохранившуюся богатую фольклорную практику, такую как Бойчечак маросими (Праздник подснежника), включенную в список нематериального культурного наследия Узбекистана (6).

Праздник подснежника у тюркских народов представляет собой обрядовый праздник со специальными песнями в честь первого цветка весны, который сначала проводился при участии взрослых, затем принял форму детского фольклора. Когда весна входит в свои права, только что появившиеся подснежники вешаются на веточки и ветки ивы, готовится кукла подснежника, и подготавливаются к обряду жертвоприношения:

Бойчечакни тутдилар,

Тут ёгочга осдилар.

Килич билан чопдилар,

Бахмал билан ёпдилар.

Взяли подснежники // Повесили на ветки тутовника. Срубили мечом // Покрыли парчой.

Дети, держащие подснежники и исполняющие песни о весне, ходили по домам, изгоняя из них зиму. Считалось, что подснежник, являющийся цветком весны, приносил в дома радость и веселье, 
счастье и удачу, изобилие и благодать (6). Мы полагаем, что единичность ассоциации вызвана процессом урбанизации: в культурном пространстве города связь с природой ослабевает, и дети на дошкольном и начальном школьном обучении изучают данный обряд рудиментарно, то есть в качестве стихотворений, песенок, рассказов преподавателя о национальных традициях. Для того чтобы увидеть сами подснежники, необходима поездка в горы, и прямой, а не опосредованный (через рассказы, картинки и фотографии) контакт с природой. Для исполнения обрядовых песен также необходим прямой контакт с социумом, что, по сравнению с малым пространством деревни (кишлака, аула), сложно осуществимо в городских условиях спальных районов. Следовательно, в культурном пространстве города наблюдается частичное, а иногда и полное прерывание цепи ассоциаций, отражающееся на обобщении и/или утрате ряда когнитивных признаков концептов концептосферы Времена года в сознании индивида.

В ряду единичных ассоциаций также присутствуют офтоб (солнце), ёшлик (молодость), иссиқ (тепло), қалдиргоч (ласточка), обхуаво (погода), уррхимчак (паук), товлар (горы), гуллаш (цветение) и қушлар (птицы), наполняющие периферийные слои концепта Весна в узбекском языке. Несомненно, современное восприятие весны в узбекской языковой картине мира, по сравнению с восприятием дехканина (земледельца), еще каких-то сто лет назад вспахивающего землю с помощью омача (соха, старинное деревянное пахотное орудие в Средней Азии), значительно переменилось, поскольку механизация труда и улучшение жизненных условий, всеобщее образование, а также мобильность передвижения позволяют больше концентрироваться на радостях бытия (праздники), чем на тяжелом изнуряющем труде ради пропитания.

Восприятие осени в узбекском фольклоре отражается более сдержанно, по сравнению с весной, летом и зимой, в пословицах отмечается перемена погоды, но не влекущая за собой такого напряженного труда, как весной и летом, или опасных для здоровья холодов, как зимой, например:

Кузги құатиқ куёвга бергисиз - Осенней простокваши жениху не нальешь. Здесь құатиқ (разновидность кисломолочной продукции) продукт, чаще употребляемый в холодном виде в летнюю жару, к тому же изготовление его помогает целесообразно употребить излишки молока, чтобы не испортились в жаркую погоду, особенно до изобретения холодильников. Но осенью, когда уже стало прохладно, логичнее подавать уважаемому человеку что-то согревающее, следовательно, подавать қатиқ не только нецелесообразно, но и неуважительно.

Осень в Узбекистане - пора вызревания поздних сортов фруктов и бахчевых культур, которые можно сушить, вялить или без всякой переработки при правильном хранении употреблять в пищу почти до окончания зимы, например:

Кузнинг бир куни құишнинг бир ойини боқуар - Один осенний день один зимний месяц кормит, т.е. заготовленные осенью посредством сушки, вяления или переработанные фрукты и овощи предназначены уже в качестве зимних запасов, тогда как летом можно свободно наслаждаться свежими плодами без ограничений.

Қирқкуякда құиндаги хқам пишар - В сентябре созревает даже то, что лежит в тени, или: в сентябре созревает даже то, что в ножнах. Это 
логично, поскольку летняя жара (чилля) спадает, вечера становятся приятно прохладными, а условия благоприятными для созревания некоторых растительных культур.

Жўжани кузда сана - Цыплят по осени считают - пословица, отражающая здравый смысл и результат упорного труда, как в буквальном, так и в переносном смысле.

Следует отметить, что в узбекских пословицах о временах года в названии месяцев употребляются староузбекские названия, которые употребляются только в исторической литературе или поэзии, как, например, в стихах Хуршида Даврона: Мезон кечди // Қандай маъюс кечди бу мезон (Хуршид Даврон, 1979) - Прошел мизан // Каким разочарованием он был (8).

В качестве примера можно выделить вышеуказанную пословицу или, например, пословицу: Қирққкуяк келди - куз келди - Наступил сентябрь - наступила осень. Қирқкуяк (сентябрь) - староузбекское слово, чисто тюркского, кипчакского происхождения, активно употребляемое, например, в казахском языке. В Ўзбек тилининг изохли луғати под редакцией Э.М. Мадвалиева его толкование отсутствует. В узбекском языке тюркские названия месяцев в свое время были заменены на арабские или персидские, а в дальнейшем, с принятием григорианского календаря, в узбекский язык пришли и были приняты такие названия, как сентябрь, октябрь, ноябрь и т.д., но в узбекских пословицах тюркское название осеннего месяца сохранилось. Примечательно, что понятие құирқұкуяк не может быть полностью идентичным современному понятию сентябрь григорианского календаря также, как и название другого осеннего месяца - мизана (октября), приходящегося на период с 22 сентября по 21 октября или саратона - тюркского аналога персидского слова чилля (период с 25 июня по 3 августа), поскольку кипчаки и другие тюркские племена ориентировались на бытовые климатические наблюдения, поведение животных, птиц (отлет и прилет) и солнечный календарь, например: Лайлак келмай, ёз бўлмас, құрдияк чопмай, куз бўлмас - Нет лета без аиста, нет осени без белок. Данная пословица опирается на наблюдения о поведении животных и птиц.

Мизон чиқиб, ақраб кирса - қиш - Уходит месяц мизан (октябрь), скорпионом крадется зима, т.е. заканчивается, наконец, теплый период и начинает ощущаться дыхание зимнего холода.

В целом, осень в Узбекистане полностью не соотносима с месяцами григорианского календаря: сентябрь является как бы продолжением лета, просто менее жарким и более приятным, поскольку период чилли уже закончился, а вечера перестали быть душными. Практически до середины или конца октября не бывает дождей; затяжные дожди, пасмурная погода, интенсивно облетающие с деревьев листья, необходимость тепло одеваться больше связаны с ноябрем. Календарная же зима, наступающая в декабре, в этот переходный период больше напоминает позднюю осень, чем зиму. Поэтому нам кажется закономерным, что относительно осени ассоциации респондентов были немногочисленны, эмоциональнонейтральны и менее разнообразны, по сравнению с весной, летом или зимой. Среди ассоциаций наблюдались преимущественно основные погодно-климатические характеристики периода и ассоциации, связанные с началом учебного года. 
Рис. 4. Представление ассоциативного ряда (облако ассоциаций) к концепту Осень в узбекском языке

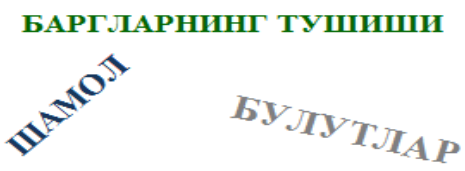

MAKTAБ
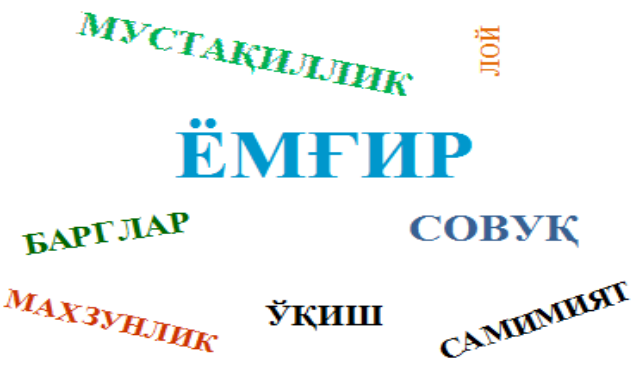

Ёмzир (дождь) и мақтаб (школа) - наиболее частые ассоциации, связанные с осенью, поскольку школьные ярмарки, появление групп детей и молодых людей на улицах в школьной и студенческой форме, необходимость семейных покупок, связанных со школой и учебой в целом, а также первые дожди после долгого засушливого периода, несомненно, являются характерными приметами периода. С этим сезоном закономерно связаны и ассоциации булутлар (облака, тучи), совуқ (прохлада, холод) и шамол (ветер). Отметим и общую ассоциацию уққиш (учеба); она возникала реже, чем мақтаб (школа), но логически взаимосвязана с последней, поскольку это период, когда и преподаватели возвращаются из отпусков к рабочим будням. Барглар (листья) и баргларнинг тушиши (листопад) ассоциации, связанные как с приятным времяпровождением, так и с учебой (и школой), поскольку осень - период, когда дети дошкольного и младшего школьного возраста учатся мастерить поделки из подсобных материалов - опавших листьев, желудей, каштанов и т. п.

Среди ассоциаций, формирующих когнитивные признаки осени

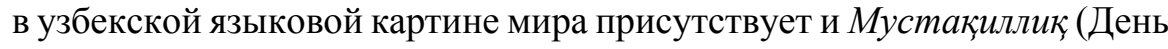
независимости) - важный государственный праздник 1-го сентября, и выходной день, в связи с которым новый учебный год в Узбекистане официально стартует не 1-го, а с последующего рабочего дня согласно календарному дню, на который он выпадает.

Ассоциации махзунлик (грусть) и самимият (искренность) эмоционально-нейтральны в контексте осени, несут элемент легкой ностальгии по уходящему лету, без страха предстоящих холодов и зимы. Ассоциация naxma (хлопок) отражает не только период вызревания главной сельскохозяйственной культуры страны, но и отмененную с 2017 года практику отправки студентов и школьников на ручной сбор хлопка.

Единичная ассоциация лой (грязь) показывает, что осень, несмотря на начинающиеся дожди, все же не является периодом, для которого характерно наличие грязи из-за особенностей местной почвы.

Ассоциации к осени в поэтической картине мира, например, в творчестве Хуршида Даврона, не только включают в себя такие национально-специфические образы, как, например, арава (арба, 
телега), полная яблок осеннего урожая, и разноцветная листва деревьев, но и следуют традициям классической русской поэзии воспевать осеннюю грусть, навеянную увяданием природы:

\author{
Кузни олиб уттди дехқонлар \\ Аравада олмалар билан. \\ Тўлиб кетди чексиз сайхонлар \\ Ғилдираклар вирчиллашидан. \\ Дарахтларнинг ранги құорайиб, \\ Бовда эсди аччиқ куюнди. \\ Куз йўллари мисли қора ип \\ Чўзилдилар - ёмвирлар ювди (8).
}

Дехкане (крестьяне, фермеры) проводили осень // С яблоками в тележке // Под бесконечный скрип колес // Цвет деревьев темнеет // Сад горько вздохнул // Осенние следы подобны черной нити // Растянулись - и смыты дождями.

Заключение. Таким образом, если анализ концепта Весна в сознании носителей узбекского языка показал его сложность и многогранность через эмоционально-положительный контекст: праздник Навруз, красоту природы и молодость, а также специфическое кушанье с особенным ритуалом его приготовления (сумаляк), особенности народного календаря трудовой деятельности (начало сельскохозяйственных работ), расцвет природы, благоприятные погодные условия и т. д., - то отношение к осени у носителей узбекского языка более нейтральное, констатирующее комфортный в климатическом отношении переход от тепла к холодам, окончание сезона отпусков и завершение сельскохозяйственных работ по сбору урожая и начало нового учебного года.

Именно весна - понятие, имеющее в узбекском языке для отражения два слова-синонима: бахқор как общепринятое и повсеместно употребляемое и куиклам - как поэтическое и стилистически возвышенное слово. Концепт Весна в узбекской языковой картине мире несет больше национально-специфических элементов в своей структуре, чем какой-либо другой из концептов концептосферы Времена года. Таковыми его делают Навруз и все связанные с ним понятия. Праздник Навруз не знаком людям, не рожденным и проживающим вне стран Центральной Азии и некоторых стран Кавказа, поэтому для объяснения им сути данного праздника потребуется развернутое объяснение $(4,67)$. Однако имеет место и такой уникальный фактор в наполнении содержания концептов Весна и Осень, как гибридизация психообразов, когда узбекистанцы, рожденные и проживающие в Узбекистане и выезжающие в Россию, вынуждены адаптироваться к другим культурным и социальным, а также погодным условиям, как, например, широкое празднование Дня Победы 9-го мая и отсутствие в календаре праздника Навруз; рано наступающая дождливая осень, пасмурное небо и серость, навевающие эмоционально-сниженное состояние.

Примечательно, что среди узбекских пословиц об осени сохранились элементы староузбекского языка в виде тюркских названий месяцев, которые точнее отражают климатические особенности региона, в отличие от общепринятых календарных месяцев. 


\section{Использованная литература}

1. Андижонда кўклам нафаси ЎзА 20.02.2013 16:09:21. — URL: http://uza.uz/oz/society/andizhonda-kklam-nafasi-20.02.2013-25382

2. Болалар учун тез айтишлар (матн): тез айтишлар / тўплаб, нашрга тайёрловчи: Иродабону Аввалбоева. - Тошкент: Юрист-медиа маркази, 2019. - 112 б.

3. Джураева М. Ю. Следы мифологических представлений и табу в узбекских народных загадках // Филологические науки. Вопросы теории и практики. - Тамбов: Грамота, 2010. № 3 (7). - С. 46-49. ISSN 1997-2911.

4. Камышева Ю., Эшпулатова А.А. Языковая репрезентация концепта «весна» в русской лингвокультуре с позиции носителя таджикского языка // Международная студенческая научно-практическая конференция «В мире русского языка и русской культуры» (Москва, 27 апреля 2017 г.): Сборник тезисов / Отв. ред.: Г. Персиянова, И.А. Орехова. - М., 2017. - С. 63-67.

5. Мехнатсеварлик ва ишёқмаслик хақида мақоллар. - URL: https://ziyouz.uz/hikmatlar/ozbek-xalq-maqollari/mehnatsevarlik-vaishyoqmaslik-haqida-maqollar/

6. Нематериальное культурное наследие Узбекистана. - URL: http://ich.uz/ru/ich-of-uzbekistan/national-list/domain-4/400-cattlebreeding-farming-gardening Last visited 29.07.2020

7. Последствия непогоды в Бухаре: 415 авто, 5300 зданий, 42 тысяч деревьев Газета.uz. — URL: https://www.gazeta.uz/ru/2020/04/28/ stormwind/

8. Хуршид Даврон, Куз шеьрлари. — URL: https://kh-davron.uz/ijod/ sherlar/xurshid-davron-kuz-sherlari.html Last visited 04.08.2020

9. Хуш келибсан Наврўзой! - URL: http://sherlaruz.com/news/sms_navro39_z_bayrami_tabriklari_sherlari_na vruz_tabriklari/1-0-66

10. Элементы, включенные в Репрезентативный список ЮНЕСКО. URL: http://ich.uz/ru/ich-of-uzbekistan/elements-included Last visited 29.07.2020

11. Ўзбек тилининг изохли луғати: Икки томли, 60000 сўз ва бирикма / Ф. Акабиров, Т.А. Аликулов, З. Зуфаров ва бошқ.; Э.М. Маъруфов тахрири остида. - М.; Русский язык, 1981. — 2-чи том. — 715 б.

12. Ўзбек тилининг изохли луғати: 80000 дан ортиқ сўз ва сўз бирикмаси. Ж.2./ Тахрир хайъати: Т. Мирзаев (рахбар) ва бошқ.; ЎзР ФА Тил ва адабиёт ин-ти. - Т.: «Ўзбекистон миллий энциклопедияси» Давлат илмий нашриёти, 2007. — 860 б.

\section{References}

1. Andizhonda kuklam nafasi (Breath of Capricorn in Andijan), available at: http://uza.uz/oz/society/andizhonda-kklam-nafasi-20.02.2013-25382

(February 20, 2013) (in Uzbek).

2. Bolalar uchun tez aitishlar (matn): tez aitishlar (Quick quotes for children (text): Quick quotes), Tashkent: Yurist-media markazi, 2019, 112 p. (in Uzbek).

3. Dzhuraeva M. Yu. Filologicheskie nauki. Voprosy teorii i praktiki, Tambov: Gramota, 2010, No 3 (7), pp. 46-49. ISSN 1997-2911. (in Russian) 4. Kamysheva Yu., Eshpulatova A.A. Mezhdunarodnaya studencheskaya nauchno-prakticheskaya konferentsiya "V mire russkogo yazyka i russkoi kul'tury" (International scientific-practical conference "In the world of the 
Russian Language and Russian Culture"), Abstracts of Papers, April 15, 2017, Moscow, 2009, pp. 63-67. (in Russian)

5. Mekhnatsevarlik va isheqmaslik khaqida maqollar, available at: https://ziyouz.uz/hikmatlar/ozbek-xalq-maqollari/mehnatsevarlik-va -ishyoqmaslik-haqida-maqollar/ (in Uzbek).

6. Nematerial'noe kul'turnoe nasledie Uzbekistana (Intangible cultural heritage of Uzbekistan), available at: http://ich.uzNematerial'noe kul'turnoenasledieUzbekistana/ru/ich-of-uzbekistan/national-list/domain 4/400-cattle-breeding-farming-gardening (July, 29, 2020) (in Russian) 7. Posledstviya nepogody v Bukhare: 415 avto, 5300 zdanii, 42 tysyach derev'ev Gazeta.uz, available at: https://www.gazeta.uz/ru/2020/04/28/ storm-wind (in Russian)

8. Khurshid Davron, Kuz she"rlari, available at: https://kh-davron.uz/ijod/ sherlar/xurshid-davron-kuz-sherlari.html Last visited 04.08 .2020 (in Uzbek).

9. Khush kelibsan Navruzoi! available at: http://sherlaruz.com/news/sms_navro_39_z_bayrami_tabriklari_sherlari_n avruz_tabriklari/1-0-66 (in Uzbek).

10. Elementy, vklyuchennye $v$ Reprezentativnyi spisok UNESKO, available at: http://ich.uz/ru/ich-of-uzbekistan/elements-included

(July, 29, 2020)

11. Ma"rufov E.M., Akabirov F., Aliқulov T.A., Zufarov Z. Uzbek tilining izohli lugati (Annotated dictionary of the Uzbek language), Moscow, 1981, vol. 2, 715 p. (in Uzbek)

12. Mirzaev T. Uzbek tilining izohli lugati (Annotated dictionary of the Uzbek language), Tashkent, 2007, 860 p. (in Uzbek) 